\title{
CONSTITUTIONAL AUTHORITY AND SUBVERSION: EGYPT'S NEW PRESIDENTIAL ELECTION SYSTEM
}

\author{
Kristen A. Stilt*
}

\section{INTRODUCTION}

It is no surprise that Egyptian President Hosni Mubarak won the September 7, 2005 elections under the new presidential election system he created. ${ }^{1}$ Many observers noted at the time that while Mubarak and his National Democratic Party (NDP) would most likely still win in 2005, at least the new system established the principle of multi-candidate presidential elections and thus the possibility of a different election result in the future. ${ }^{2}$ Mubarak started the constitutional amendment process on Feb. 26, 2005, giving the legislature very detailed instructions to prepare the text of an amendment in order to change the presidential selection system from a single-nominee referendum to a multi-candidate election. The legislature prepared and adopted the text of the amendment and submitted it to a national constitutional referendum on May 25, 2005, amidst protests ranging from objections over the

\footnotetext{
* Assistant Professor, University of Washington Law School. I thank the University of Washington Law School for funding that allowed me to conduct research for this article in Cairo, Egypt, in Summer 2005. I am grateful to my colleagues at the University of Washington Law School for the opportunity to present this work at a faculty colloquium and the faculty workshop facilitated by Professor Louis Wolcher and for the helpful comments made at these forums. Professors Ellis Goldberg, Joel Ngugi, and Dongsheng Zang of the University of Washington and Professor Tamir Moustafa of the University of Wisconsin were invaluable in discussing the comparative and Egyptian constitutional issues. I am grateful to Joanna Wilson for her superb research assistance. Finally, I thank the students in my Spring 2006 Comparative Constitutional Law course at the University of Washington Law School for their enthusiastic participation in conversations about the issues addressed in this article.

Note on transliteration: I am using a simplified version of the standard Library of Congress transliteration system, such that long vowels are not indicated nor are the dots under the consonants that require them. The hamza and "ayn are transliterated. Spellings of Egyptian names that have a conventional English spelling, such as "Hosni," will be spelled as such. For Egyptian authors who have adopted a modified transliterated form of their names in English, such as Awad al-Morr and Adel Sherif, their names will be spelled herein according to the spellings the authors have themselves chosen.

1. According to official reports, Mubarak was elected with $88.57 \%$ of the votes. Twenty-three percent of registered voters voted. Mubarak yu'adi al-yamin al-qanuniya liwilaya jadida yaum al-thalatha' 27 sibtambir [Mubarak Takes the Oath for a New Term of Office on Tuesday, September 27], AL-AHRAM, Sept. 11, at 1; Michael Slackman, Egypt Holds a Multiple-Choice Vote, but the Answer is Mubarak, N.Y. TumEs, Sept. 8, 2005, at A1. For an analysis of the conduct of the elections from a prominent unofficial monitoring group, see Press Release, Arab Center for the Independence of the Judiciary and the Legal Prof., Free, Partial and Unfair Presidential Elections (Sept. 11, 2005) (on file with author).

2. See, e.g., Michael Slackman, In Egypt, Mixed Views of Politics with a Field of
} Choices, N.Y. TIMES, Sept. 4, 2005, at 14. The next presidential elections will be held in 2011. 
content of the amendment to the lack of an independent monitoring body for the referendum voting process. ${ }^{3}$ According to the official results, fifty-four percent of the nation's registered voters voted in the referendum and eightythree percent of the voters approved the amendment. ${ }^{4}$ There have, however, been allegations of fraud in the voting process. 5

The Egyptian constitutional amendment is an excellent example of constitutional politics in a legal system that is in the crucial and vulnerable phase of determining power allocations among the executive, legislative, and judicial branches. While the most recent Egyptian constitution, adopted in 1971, specifies the rights and responsibilities of these three branches, the country is still heavily engaged in the process of filling out the meaning of this text in practice. The amendment that restructured the presidential election system is truly a major development in this process, but it does not represent "one step in the march towards ... full democracy," 6 nor does it mean that the government wants to provide candidates and voters with greater access to the presidential election process. The new system is authoritarian. While on the surface it looks as though it opens the presidential elections to multiple candidates, its actual goal and effect thus far is to perpetuate the rule of the NDP. Further, by entrenching the new election system through a detailed constitutional amendment, the Egyptian regime has subverted the powers of the Supreme Constitutional Court (SCC) to score a significant victory for the executive and legislative branches in their ongoing cold war with the SCC.

Most recent scholarship on constitutional change is grounded in an evolutionary model of legal development in which nations proceed from authoritarian forms of government to democracy and economic liberalism. This kind of scholarship analyzes the role a new constitution plays in the process of transition, and evaluates the constitution according to whether, and how, it impedes or assists the country's progress. ${ }^{7}$ The countries that have undergone

3. See infra note 74 and accompanying text.

4. Al-muwafaqa 'ala ta'dil al-dustur bi-aghlabiya kasiha [Approval of the Amendment to the Constitution by a Sweeping Majority], AL-AHRAM, May 27, 2005, at 1 .

5. Hassan M. Fattah, World Briefing Middle East: Egypt: Multicandidate Vote Approved, N.Y. TMMES, May 27, 2005, at A1.

6. Press Release, Condoleezza Rice, Secretary of State of the United States, (Sept. 10, 2005), available at http://www.state.gov/secretary/ $\mathrm{rm} / 2005 / 52966 . \mathrm{htm}$. In addition to disagreeing with the conclusions of this statement, I contest that there is a concept of "full democracy" that can be used to measure the progress of the Egyptian or any other political system.

7. See, e.g., Ruti Teitel, Transitional Jurisprudence: The Role of Law in Political Transformation, 106 YALE L.J. 2009 (1997) [hereinafter Transitional Jurisprudence]. "The 'transitional' period begins right after the revolution or political change; thus the problem of transitional justice arises within a bounded period, spanning two regimes. In the contemporary period, the use of the term 'transition' has come to mean change in a liberalizing direction[.]" Id. at 2013 (footnote omitted). See also ThE CONSTITUTION AS AN INSTRUMENT OF CHANGE 15 (Eivind Smith ed., 2003) (noting that "the different forms of constitution-making that took place in the early 1990s can only be understood as expressions of these countries' will to rid themselves of the past and enter a new era"); RUTI TEITEL, TRANSITIONAL JuSTICE (2000) 
or are undergoing these kinds of changes typically are called "transitional," with the normative assumption that they are transitioning from a repressive regime to a liberal, democratic political system. ${ }^{8}$ The transition may be accompanied by what Ran Hirschl sees as a global trend of the transfer of "an unprecedented amount of power from representative institutions to judiciaries. Most of these polities have a recently adopted constitution or constitutional revision that contains a bill of rights and establishes some form of active judicial review."9

The new constitutions of central and Eastern Europe are popular subjects for studies of constitutional change. ${ }^{10}$ South Africa's recent history is also marked by a new political and constitutional structure as a product of its transition to a post-apartheid society. ${ }^{11}$ The renewed scholarly interest in foreign constitutions, however, has not extended very far beyond these types of constitutional contexts. ${ }^{12}$ Constitutional scholarship has not yet been able to

[hereinafter TRANSITIONAL JUSTICE]. "Transitional constitutions are simultaneously backwardand forward-looking, informed by a conception of constitutional justice that is distinctively transitional." Id. at 191.

8. E.g., Teitel, Transitional Justice, supra note 7.

9. Ran Hirschl, The Political Origins of the New Constitutionalism, 11 IND. J. GLOBAL LEGAL STUD. 71, 71 (2004) [hereinafter New Constitutionalism].

10. See, e.g., Vicki C. Jackson \& Mark Tushnet, INTRODUCTION TO DEFINING THE FIELD of Comparative Constitutional LaW, xi, xiii (Vicki C. Jackson \& Mark Tushnet, eds., 2002).

The present generation's interest in comparative constitutional law has been fueled, we think, by the confluence of the great wave of constitutional reform that flowed around the world-from Central and Eastern Europe to South Africa and Latin America-in the 1980s and 1990s, with the development of a strong Id. community associated with international human rights.

The most recent new constitutions that have received extensive attention are those of Iraq and Afghanistan. For a discussion of Iraq's constitutional progress, see Kristen A. Stilt, Islamic Law and the Making and Remaking of the Iraqi Legal System, 36 GEO. WASH. INT'L L. REV. 695 (2004).

11. See Ran Hirschl, The Political Origins of Judicial Empowerment through Constitutionalization: Lessons from Four Constitutional Revolutions, 25 LAW \& SoC. INQUIRY 91, 93 (2000) [hereinafter Constitutional Revolutions].

12. H.W.O. Okoth-Ogendo laments that the scholarly community has generally disregarded African constitutions. H.W.O. Okoth-Ogendo, Constitutions Without Constitutionalism: Reflections on an African Political Paradox, in CONSTITUTIONALISM AND DEMOCRACY 65, 66 (Douglas Greenberg, et. al. eds., 1993). His main explanation is the general belief that constitutions must be part of a constitutional structure in order to be meaningful; they must "limit governmental authority" and "regulate political processes in the state," or in other words, display "constitutionalism." Id. He also criticizes scholars for "a totally inadequate conception of law and its relationship to power in Africa." Id.

The dilemma is whether to abandon the study of constitutions altogether on the ground that no body of constitutional law or principles of constitutionalism appears to be developing, and might, in all probability fail to do so; . . or to continue teaching and pontificating upon those liberal democratic values in the hope that state elites in Africa will eventually internalize and live by them.

Id .(emphasis in original). One recent exception to this lack of literature is Mirna E. Adjani, African Courts, International Law, and Comparative Case Law: Chimera or Emerging Human Rights Jurisprudence, 24 MICH. J. INT'L L. 103 (2002). 
address adequately constitutional change that moves in non-linear patterns, when the sources of political power within the particular country are engaged in a struggle over issues particular to the local context by means of the constitution. ${ }^{13}$ As Ruti Teitel has noted, in such cases "[w]here the prior regime has not collapsed, and where the political shift occurs only as a result of negotiations, constitutions play a role not well accounted for within prevailing constitutional theory."14 Indeed, constitutional change that does not fit the prevailing models of transition has been neglected in legal scholarship for a number of reasons, including that the country's constitutional politics are unenlightened and not worth attention and that the change fails to exhibit enough stability or clear trajectory to make constitutional study meaningful or possible.

Since studies of "transitional" constitutions have dominated the field of non-traditional constitutional scholarship, there remains a large category of unexamined constitutions that have undergone change and emendation but in less clear directions. In these contexts of ambiguity, legal scholars are generally unable to account for, analyze, or productively discuss the role of the constitution in the shaping of a country's legal system and national existence more generally. Instead, doctrinally-focused and positivist approaches are often used as a deeply unsatisfying default option.

This article urges study of constitutional change in under-examined constitutional settings, taking the recent developments in Egypt as a prompt to undertake just such a study. This article demonstrates that sociological, anthropological, historical, linguistic, and political science approaches must be brought to the study of constitutional change in order to gain meaningful insights. This article also challenges an evolutionary model of transition as the standard by which to choose which constitutions receive scholarly attention, and it shows the value of attempting to explain constitutional change on its own terms and in its own context. As a comparative law scholar, I believe my range of perspective and inquiry should be broad, from the internal perspective of the Egyptian actors involved, a perspective which I have attempted to access

13. Recognizing a related lacuna, Noah Feldman called upon comparative constitutional law scholars to "promote conceptual clarity by finding a way to talk about partial rule of law and partial constitutionalism." Noah Feldman, Review: Constitutions in a Non-Constitutional World: Arab Basic Laws and the Prospects for Accountable Government, 1 INT'L J. CONST. L. 390, 391 (2003) (reviewing Nathan J. Brown (2002)).

14. Teitel, Transitional Jurisprudence, supra note 7, at 2059. Scholars have dealt with the reasons for the promulgation of constitutions in countries that lack "constitutionalism." See, e.g., Nathan J. Brown, Constitutions IN A NonCOnstitutional World (2002). Brown presents "various nonconstitutionalist motives for writing constitutions" in the Arab world. Id. at 3. His main explanations for the purpose of producing constitutions that "are not meant to limit governments" are (1) sovereignty: a "country proclaims its independence (or a revolutionary regime proclaims its triumph) by writing a constitution"; (2) "constitutions may serve the purpose of proclaiming basic ideology"; and (3) "a constitution may serve to make lines of authority clear without restricting the actions of senior leaders." Id. at 10-11. Brown's significant work helps to explain the initial impetus for constitutions such as the Egyptian one. 
through extensive research in Egypt, to the external perspective of a scholar analyzing and writing about the events from the distance of a U.S. university campus. Comparative legal scholars must strive to attain multiple perspectives in order to bring as much clarity of meaning as possible to a legal event and its larger social contexts. ${ }^{15}$

Egypt's constitution is currently being used to express legal authority and to subvert legal authority. On one hand, the SCC has over the past twenty-five years developed as a strong and independent institution and, while upholding the administration's position in many areas of the law, particularly economic, has also not refrained from striking legislation as unconstitutional. ${ }^{16}$ The executive, and the legislature it dominates, have generally been willing to tolerate some losses before the SCC in exchange for its larger support of the regime's agenda. ${ }^{17}$ In the process of more than two decades of jurisprudence that has been taken seriously by the executive, legislative, and judicial branches, the SCC has not only established itself as a strong authority but also established the constitution as a meaningful text. ${ }^{18}$

A prime example of Egypt's dueling constitutional authority and subversion is the new presidential election system. In fashioning the legal mechanisms to implement this system, the administration constitutionally entrenched the legal provisions in an attempt to protect them from later review or invalidation by the SCC. Thus, the regime introduced the new election system as a lengthy constitutional amendment that contains a level of detail unprecedented in the Egyptian constitution. The administration's motives are clear and, in defense of the constitutional amendment, Fathi Sorour, Speaker of the lower legislative house, commented that part of the constitution cannot be declared unconstitutional. ${ }^{19}$ The amendment also dictated the SCC's actions by requiring that it review a draft of the amendment's implementing legislation in

15. The benefits of understanding such changes accrue on many levels, depending on the particular position of the user of the knowledge. Even if the goal is to encourage "transition" in Egypt in the Eastern European sense of the word, policy makers still must begin with understanding the developments in Egypt on their own terms.

16. See infra note 38 and accompanying text.

17. The connection between President Mubarak's ruling National Democratic Party (NDP) and the almost complete domination of the legislature by the NDP is discussed infra note 61 and accompanying text. The regime's losses before the SCC are minor compared to the dramatic changes that dismantled the regimes of Eastern Europe in the 1990s. The Egyptian administration has no intention of introducing or allowing significant reforms, and it is relying on the United States to not insist on such dramatic reforms on the basis that the United States would not want an Islamist-dominated government to come into power, which is what is widely expected to happen if there were genuinely free and fair elections in Egypt.

18. The reasons for executive and legislative respect for, or tolerance of, the SCC is discussed infra notes $29-41$ and accompanying text.

19. See Noha El-Hennawy, The Race is On, EgYPT TodAy, June 2005, available at http://www.egypttoday.com/article.aspx?ArticleID=5234 [hereinafter The Race is On]. This issue was recently presented to the SCC. See infra notes 166-170 and accompanying text. 
a pre-promulgation abstract review, a power not otherwise provided to the SCC. ${ }^{20}$

Part One of this Article introduces Egypt's constitutional protagonist: the SCC. The SCC's position is central in the discussion of the election system amendment. Due to the important role that the SCC has gained over the past twenty-five years, the Egyptian administration used a detailed constitutional amendment to attempt to prevent the SCC from reviewing the constitutionality of the election system. Ironically, the regime feared the SCC's power and independence, which has developed over time with the regime's acquiescence. Otherwise, the regime could have implemented the election change through a short constitutional amendment and expanded upon it through lengthy legislation.

In Part Two, this Article discusses the constitutional amendment and its political and legal context. For the constitutional referendum, reformist movements had to choose between the remote possibility that another candidate could have won in the 2005 election under the new system versus the long-term damage of the amendment to the cause of free and fair multi-candidate presidential elections. Delving into more detail, Part Three discusses the two main aspects of the amendment and its concomitant implementing legislation: first, access by potential presidential candidates to inclusion on the ballot; and second, monitoring of the elections. This part will show that the amendment and implementing laws make it very difficult for a non-NDP candidate to run for president in light of current political realities. The major obstacle to nonNDP candidates obtaining a listing on the presidential ballot is the NDP's tight control of the legislature, which can be changed only by a thorough reform of the political party system. In addition, the election monitoring system put in place by the amendment and accompanying laws is troubling. Egypt has a history of election irregularities and outright fraud, which were extensively documented for the 1995 and 2000 legislative elections and have been reported with regard to the 2005 legislative elections. ${ }^{21}$ Until the issue of the fairness of the electoral process is adequately resolved, the conduct of presidential elections undoubtedly will be subject to criticism. ${ }^{22}$

In Part Four, the Article investigates the tension between constitutional authority and subversion by discussing the two largest issues surrounding the amendment: legislating through the amendment and tampering with the SCC's power of judicial review. Both are efforts to subvert the power of the SCC; they recognize the SCC's power, and harness that power to essentially tie the SCC's hands.

The article concludes with an urging to constitutional scholars to work in new, complex, and confusing areas. This challenging work yields a range of

20. See judicial review and interpretation powers, infra notes 33-37 and accompanying text.

21. See infra Part III.B.1.

22. See discussion of election monitoring standards infra Part III.B.2. 
benefits. New problems produce new approaches, and new approaches can then be used in more familiar contexts to bring fresh perspectives to what may have formerly seemed like well-studied and understood home territory.

\section{EgYPT'S CONSTITUTIONAL ANCHOR: THE SUPREME CONSTITUTION COURT}

The SCC in its present form is a relatively new institution. The Supreme Court, established in 1969 by a presidential decree of President Nasser, was the SCC's predecessor. ${ }^{23}$ In contrast to the extensive powers that would be given to the SCC, Nasser structured the Supreme Court so that the executive heavily controlled it and it served Nasser's socialist policies. He granted the Supreme Court the exclusive power of judicial review and abolished the previous system of abstention, whereby any court could abstain from enforcing a law it found to violate the constitution. The weakness of the abstention system from the perspective of judicial power was that a law that a court failed to apply was not considered unconstitutional and was still in effect; it just was not applied in that particular case. For the legislature and the executive, the system of abstention created a lack of legal uniformity and subjected state policy to the decisions of every judge in the country. ${ }^{24}$ Consolidating the power of judicial review in one institution made it easier to control, and Nasser's Supreme Court was a tool of the regime. The President appointed justices for three-year terms. ${ }^{25}$ Not surprisingly, the decisions of the Supreme Court were uniformly pro-state.

Nasser's death in 1970 led to profound changes in Egypt's economic and legal systems. Nationalizations and socialist policies had caused investor flight. As Nasser's successor, President Anwar Sadat attempted to reverse this nationalist economic policy, and one of his first major actions was to propose the drafting of a new constitution that would protect private property rights along with continuing to recognize the importance of the public sector. The new constitution was adopted in 1971 and Arts. 174-178 provided for a new Supreme Constitutional Court to replace the former Supreme Court. ${ }^{26}$ Despite the new constitution and new legislation, Sadat discovered that attracting foreign capital required more than textual assurances that Nasser's policies had

23. Presidential Decree enacting Law 81 (1969), AL-JARIDA AL-RASMIYA [Official Gazette] No. 35 Supp., 678-680 (Aug. 31, 1969). See also Awad Mohammad El-Morr, Abd ElRahman Nossier, \& Adel Omar Sherif, The Supreme Constitutional Court and its Role in the Egyptian Judicial System, in HuMAN RIGHTS AND DEMOCRACY: THE ROLE OF THE SUPREME CONSTITUTIONAL COURT OF EGYPT 37 (Kevin Boyle \& Adel Omar Sherif eds., 1996) [hereinafter Human RIGHTS AND DEMOCRACY]. The Court of Cassation predated the Supreme Court and served, and still serves, as the highest court of appeals in Egypt.

24. See Awad Mohammad El-Morr \& Adel Omar Sherif, Democratic Participation, in HUMAN RIGHTS AND DEMOCRACY, supra note 23, at 75, 78.

25. Presidential Decree enacting Law 81, supra note 23.

26. AL-DUSTUR AL-MISRI [Egyptian Constitution] (amended 2005) [hereinafter Egyptian Constitution]. 
been reversed. ${ }^{27}$ The SCC needed the power to guarantee the property rights contained in the constitution and legislation. ${ }^{28}$

Thus, President Sadat introduced Law 48 of 1979 as the implementing legislation to launch the SCC. ${ }^{29}$ As part of Law 48, the SCC obtained the power of judicial review and the members of the SCC are not subject to removal. ${ }^{30}$ The SCC is composed of a President, considered the chief judge, and an appropriate number of members; no specific number is given in Law 48 nor the criteria for what constitutes an appropriate number. ${ }^{31}$ The President of Egypt appoints the President and the other members of the SCC to life terms. ${ }^{32}$

The SCC has the power of judicial review of laws and regulations in two ways. ${ }^{33}$ First, in the course of deciding a case on the merits, if a court or any judicial forum views prima facie that a provision of a law or regulation upon which the settlement of the dispute depends is unconstitutional, the court suspends the proceedings and forwards the case to the SCC for the adjudication of the constitutional issue. ${ }^{34}$ Secondly, when the constitutionality of a provision in a law or regulation is contested by a party to a case before a court or other

27. See Tamir Moustafa, Law Versus the State: The Expansion of Constitutional Power in Egypt, 1980-2001, at 68 (2002) (unpublished Ph.D. dissertation, University of Washington) (on file with author) [hereinafter Moustafa, Law Versus the State]. A revised version of Moustafa's dissertation is forthcoming from Cambridge University Press. The concept of providing additional reassurances to investors is referred to as a "credible commitment." See Douglass C. North \& Barry Weingast, Constitutions and Commitment: The Evolution of Institutions Governing Public Choice in Seventeenth-Century England, 49 J. OF ECON. HIST. 803, 803 (1989).

The more likely it is that the sovereign will alter property rights for his or her own benefit, the lower the expected returns from investment and the lower in turn the incentive to invest. For economic growth to occur, the sovereign or government must not merely establish the relevant set of rights, but must make a credible commitment to them.

Id.

28. According to then Prime Minister Mustafa Khalil:

There were efforts to encourage foreign investment in Egypt at the time because we were dealing with a fiscal crisis. One major factor that was impeding investment was the lack of political stability - both foreign and domestic. We issued a number of laws aimed at guaranteeing private investment .... But a major problem was that the NDP, having the majority in the People's Assembly, could push through any legislation it wanted and change the previous laws. This was at the forefront of Sadat's thinking when he created the Supreme Constitutional Court. He primarily wanted to make guarantees [to investors] that laws would be procedurally and substantively sound.

Moustafa, Law Versus the State, supra note 27, at 72-73 (conducting personal interview with Mustafa Khalil (June 14, 2000)).

29. Law 48 (1979), Al-JARIDA AL-RASMIYA [Official Gazette] No. 36, 530-538 (June 9, 1979).

30. Id. at arts. 11, 28.

31. Id. at art. 3.

32. Id. at arts. 5, 11 .

33. Id. at arts. 25-27.

34. Id. at art. 29(a). 
judicial forum, and the grounds of the contestation are found to be plausible by the court, the court must postpone the case and grant the party a delay of three months, during which time the party petitions for the SCC to hear the constitutional claim. If the SCC does not decide the constitutional issue within the three-month period, the case resumes without resolution of the constitutional question. ${ }^{35}$

As a separate matter, the SCC also has the power of statutory interpretation. ${ }^{36}$ The Prime Minister, the Speaker of the lower legislative house, or the Supreme Council of the Judiciary may ask the Minister of Justice to make a request for statutory interpretation to the SCC. The request for interpretation must state the legislative provision at issue, the divergent points of view surrounding its application, and the degree of importance of its uniform application. ${ }^{37}$

The SCC indeed has invalidated laws on constitutional grounds and has become the most significant institution in Egypt for challenging the executive and the NDP-dominated legislature. ${ }^{38}$ Despite this, neither Sadat nor Mubarak has attempted to abolish the SCC, although Mubarak has continually made efforts to undermine its power when it has been in the regime's interest to do so. In general, the expansion of judicial power is commonly perceived as an accompaniment to liberal values. ${ }^{39}$ Yet Sadat, and Mubarak after him, did not embrace these values nor establish, and then tolerate, the SCC as part of a larger democratic package. ${ }^{40}$ Rather, the "expansion of judicial power has occurred in Egypt despite its authoritarian system. Moreover, the judiciary became the main engine of political reform and for some time this role was paradoxically facilitated by the executive branch of the government itself." ${ }^{, 41}$ The enduring power of the SCC has been somewhat of an enigma, for why would an entrenched authoritarian regime that has already distanced itself from the policies of the Nasser period continue to allow an independent constitutional court empowered to perform judicial review $?^{42}$

35. Id. at art. 29(b).

36. Egyptian Constitution, supra note 26, at art. 175.

37. Law 48 (1979), supra note 29, at art. 33.

38. Tamir Moustafa, Law Versus the State: The Judicialization of Politics in Egypt, 28 LAW \& SOC. INQUIRY 883, 883-84 (2003) [hereinafter Moustafa, The Judicialization of Politics in Egypt].

39. See New Constitutionalism, supra note 9, at 72 (recognizing and criticizing this commonly-held view).

40. Hirschl is skeptical of the notion that a trend toward constitutionalization is "driven by politicians' genuine commitment to democracy, social justice, or universal rights." Id. at 72 . He proposes that "it is best understood as the product of a strategic interplay among hegemonic yet threatened elites, influential economic stakeholders, and judicial leaders." Id. While this is helpful in rejecting the march to democracy concept of constitutionalization, it is only the first step towards explaining the Egyptian case.

41. Moustafa, Law Versus the State, supra note 27, at 3.

42. See Moustafa, The Judicialization of Politics in Egypt, supra note 38, at 883. 
While serving the ongoing function of providing guarantees to investors that property rights will be respected, the SCC has also gained enough power to challenge the regime on non-economic issues. In particular, opposition parties and human rights activists turn to the SCC for relief and are often successful. The government created a double-edged sword in the SCC, and on balance is willing to tolerate its losses before the court in exchange for the SCC's protection of private property that allows the government to attract desperately needed investments. ${ }^{43}$ Further, the SCC's rulings throughout the 1990s helped to advance the regime's domestic economic liberalization policies. ${ }^{44}$ Thus, the government had to work within the context of the SCC's power and authority when devising the new presidential election system.

\section{MUBARAK'S PROPOSALS, THE CONSTITUTIONAL AMENDMENT, AND REFERENDUM}

\section{A. Mubarak's Proposals}

On February 26, 2005, Egyptian President Hosni Mubarak issued a dramatic correspondence to the two houses of the Egyptian Parliament, the lower People's Assembly (PA) and the upper Consultative Assembly (CA). He requested that the two bodies initiate a process to amend the constitution to establish presidential elections in which the voting populace would elect the president in secret, general, and direct elections. ${ }^{45}$ His statement was widely printed the following day in the major newspapers in Egypt. ${ }^{46}$

This announcement called for the most significant change in the Egyptian political process since the coup led by Nasser in 1952. At the time of the announcement, the presidential election process was prescribed by Article 76 of the Constitution:

The PA nominates the president of the Republic, and presents the nominee to the citizens to vote on the candidate in a referendum.

43. See $i d$.

44. See id. Policies such as liberalization of the housing market were not popular with Egyptians other than the wealthier classes, and the government wanted another body to take responsibility for unpopular decisions.

45. Egyptian Constitution, supra note 26, at art. 189 (stating the constitutional amendment process).

46. Nass kitab Mubarak ila ra'isay majlisay al-sha'b w-al-shura bi-ta'dil al-mada 76 min al-dustur [Text of the Speech of Mubarak to the Presidents of the PA and CA Regarding the Amendment of Article 76 of the Constitution], AL-AHRAM, Feb. 27, 2005, at 1 (AL-AHRAM is the major government paper and is widely read). 
The nomination in the PA for the position of President of the Republic is achieved on the basis of the proposal of at least one-third of the PA's members, and the candidate who gains the votes of two-thirds of the members of the PA is presented to the citizens to vote on the candidate in a referendum. If no candidate receives a two-thirds vote in the PA, then the nomination process is repeated two days later from the date of the first vote, and the candidate who receives votes from an absolute majority of the members of the PA is presented to the citizens to vote on the candidate in a referendum.

The candidate is considered the President of the Republic with the receipt of an absolute majority of [positive] votes from those who voted in the referendum. If the candidate does not receive a majority of votes, the PA nominates a different candidate and follows the same procedures with regard to the nomination and public vote. ${ }^{47}$

As indicated by the original Article 76, the lower house, the PA, which has been heavily dominated by the ruling NDP, tightly controlled the process. ${ }^{48}$ Since taking office upon the assassination of Anwar Sadat in 1980, Mubarak has succeeded in this referendum process four times with "yes" votes in the mid to high ninety percent range. ${ }^{49}$ The presidential term of office is six years, and the constitution does not provide for a limit on the number of terms. ${ }^{50}$

Mubarak's February 26, 2005, letter was carefully crafted to explain the impetus and need for the amendment and to suggest a substantial amount of detail for the PA to include in the amendment, which it faithfully did. Mubarak's statement touched on many key aspects of Egyptian political and legal history, and he was sending clear signals to the NDP while also attempting to convince the population of the genuineness of his desire for reform. After explaining that his remarks were part of proposing a procedure for amending the constitution, he stated:

For the purpose of strengthening our democratic future which we are fervently striving for, and out of our desire to carry out the choice of the President of the Republic, for which the

47. Egyptian Constitution, supra note 26, at art. 76 (prior to amendment of May 25, 2005).

48. See note 61 and accompanying text.

49. In 1999, according to official results, Mubarak received ninety-four percent positive votes. U.S. Dept. of State, Egypt, Country Reports on Human Rights Practices - 2004, at http://www.state.gov/g/drl/hrrpt/ 2004/41720.htm (Feb. 28, 2005) [hereinafter Egypt Country Reports].

50. Egyptian Constitution, supra note 26, at art. 77. 
election date is approaching, with that which will achieve development and support for the democratic system and raise the role of the people, who possess the power, therefore, I have viewed my responsibility to include requesting an amendment of article 76 of the constitution and adding a new article to its text at the end of article 192.

I would like to place in front of the representatives of the people some basic principles that I view as guaranteeing the achievement of the goal of the amendment:

1. The election for the President of the Republic [should be] conducted by direct, general, and secret vote by all individuals who have the right to vote.

2. All of the guarantees to provide for the presentation of more than one candidate to the people [should be] established so that the people can choose from them according to their free desire.

3. A pledge of the necessary measures to respect the serious nature of the nomination of candidates for president, including that whoever desires to be nominated [should] achieve the support from the elected representatives of the people in institutions recognized by the constitution and in regional parliaments.

4. Granting the opportunity to the political parties to nominate one of their leaders according to the rules that you deem appropriate in order to enter the first presidential elections to take place in light of this amendment.

5. Formation of a high commission, which will be guaranteed complete independence and neutrality and which will provide all of the procedures, and undertake supervision over the electoral process from the submission of the names of the candidates to the announcements of the results of the election, provided that included in its formation is a number of presidents of the judicial bodies and a number of general personalities. 
6. The voting in the elections for the President of the Republic [should take place] on one day.

7. Laying down guarantees for the establishment of judicial monitoring over the process of voting. ${ }^{51}$

These suggestions for the new presidential election system and the constitutional amendment are very detailed and are all designed to protect the dominance of the NDP. First, Mubarak's statement that candidates for president should have the ability to serve the nation and should have support from members of constitutional and elected popular institutions is selfserving. ${ }^{52}$ By stressing that candidates should have the support of elected members of the legislatures, he intended to sideline candidates who may not belong to a political party or enjoy wide support in the NDP-dominated elected bodies.

Second, Mubarak also called for the formation of an independent election commission to supervise the electoral process, from the presentation of the candidates' names to the announcement of the results. This commission should include a number of leaders of "judicial bodies." The role of "judicial bodies" in Egyptian elections has been a contentious issue and will be explained in detail below. By using this term, Mubarak was sending a message to judges that they would have some role in election monitoring, without specifying the details of that role, with the intent to appease judges who have demanded complete supervision over the entire election process. ${ }^{53}$

Mubarak had to justify his proposed constitutional amendment to his citizenry. Coming soon after President Bush's February 2, 2005 State of the Union address, in which he called upon Mubarak to lead the Middle East to democracy, Mubarak had to make clear that he was not merely succumbing to American pressure. ${ }^{54}$ Accordingly, Mubarak was careful to place his proposal in the context of a national narrative in which these changes would be the obvious next step. He described the work of the drafting committee for the 1971 Constitution and the choices they made in structuring presidential elections. According to Mubarak, they considered two options: direct presidential elections or allowing the legislature to choose the president. As he described the events, the drafters chose to blend these two options, such that the legislature chooses the candidate whom the people then accept or reject.

51. Text of the Speech of Mubarak to the Presidents of the PA and CA Regarding the Amendment of Article 76 of the Constitution, supra note 46, at 1.

52. Id.

53. See infra notes $123-128$ and accompanying text.

54. President George Bush, State of the Union Address (Feb. 2, 2005), www.whitehouse.gov/news/ releases/2005/02/print/20050202-11.html. "And the great and proud nation of Egypt, which showed the way toward peace in the Middle East, can now show the way toward democracy in the Middle East." Id. 
Mubarak stated that the process chosen by the drafters in 1971 was a typical process for countries undergoing democratic transition. He further clarified that the system provided Egypt with security and stability until she was able to completely free her soil of the enemy who invaded her. This is clearly an illusion to the perceived need to maintain tight control at home in the face of tense relations with Israel. ${ }^{55}$ Further, Mubarak produced internal justifications to ward off allegations that his actions were at the urging of the U.S. administration or as a preventive measure to protect Egypt from an American imposition of democracy in Egypt. ${ }^{56}$

Mubarak's letter to the PA and CA specified his ideas for the content of the constitutional amendment and then later the implementing legislation. The result was to allow the president to dictate the rules under which he would run for re-election, and then give those rules constitutional protection.

\section{B. The Constitutional Amendment}

This section describes the content of the amendment in preparation for the discussion of the implementing legislation in Part Three and then the larger argument in Part Four that the amendment represents constitutional authority and subversion. The overall content of the amendment is discussed here with the key issues clustering around two topics, which will also be the organization used in Part Three: access of candidates to inclusion on the ballot and the monitoring of the elections. These are two of the main areas of concern surrounding legislative elections, and the SCC has heard a number of claims seeking to invalidate legislative elections on these grounds. Accordingly, it is to be expected that these are the two main areas in which the President wanted to incorporate his presidential election rules into the amendment in order to protect them from later invalidation by the SCC.

A detailed analysis of the amendment is necessary because the amendment is itself detailed and lengthy. Unlike the original Article $76,{ }^{57}$ the amended version looks far more like legislation than an article from the Egyptian constitution. While constitutional provisions generally are of dramatically varying lengths, as are constitutions themselves, the style of the amended article is completely different from the original article or any other article of the Egyptian constitution. ${ }^{58}$ This amendment was carefully crafted

55. Text of the Speech of Mubarak to the Presidents of the PA and CA Regarding the Amendment of Article 76 of the Constitution, supra note 46, at 1.

56. See, e.g., al-Tarshih lil-intikhabat al-ra'isiya nihayat al-usbu' al-muqbil [The Nomination Process for the Presidential Elections Takes Place at the End of Next Week], ALAHRAM, July 13, 2005, at 1 (citing the Egyptian ambassador to the United States as stating that Mubarak was not under any American pressure to undergo a democratic transformation). The historical backdrop of this speech, of course, was the 2003 American invasion of Iraq.

57. See supra note 47 and accompanying text.

58. Some U.S. state constitutions, for example, are notoriously lengthy and detailed, but they are internally consistent in this style. For examples, see Christian Fritz, Constitution 
and the level of detail strategically chosen to entrench as much of the presidential election system as possible in the constitution.

\section{Access to the Ballot by Candidates}

According to the amendment, there are two ways to become a candidate. First, political parties that have been in existence for five consecutive years prior to the beginning of the presidential election period, and that in the last election received at least five percent of the seats in both the PA and the CA, may nominate one of their leaders as a candidate. ${ }^{59}$ However, prior to the 2005 presidential elections, only the NDP met the five percent rule. ${ }^{60}$ At that time, the PA was dominated by 402 NDP members out of a total of 454 seats. Four opposition parties held a total of 16 seats: New Wafd Party had seven; Tajammu' held six; the Nasserists held two; and the Liberal Party held one. Independent candidates known to be affiliated with the Muslim Brotherhood held 17 seats, independent Nasserist candidates held five seats, and unaffiliated independent candidates held 14 seats. Ten seats were filled by presidential appointment and thus those appointees were loyal to Mubarak's NDP. ${ }^{61}$

Since the constitutional amendment was supposed to change the presidential selection process into a multi-candidate election, it would have reflected very poorly on Mubarak if he were the only candidate in the first election under the new system. Consequently, the constitutional amendment contained a waiver of the minimum seat requirement for party-sponsored candidates for the first election under the new system. ${ }^{62}$ The amendment provided that for the first election, each political party was permitted to nominate one member of their leadership body, provided the leadership body was formed prior to May 10, 2005..$^{63}$ Mubarak hinted at this type of waiver in point four of his Feb. 26, 2005 statement when he suggested that the rules should facilitate the entry of the leaders of political parties into the first presidential elections to take place after the adoption of the amendment. ${ }^{64}$

Making in the Nineteenth-Century American West, in LAW FOR THE ELEPHANT, LAW FOR THE BEAVER: ESSAYS IN THE LEGAL HISTORY OF THE NORTH AMERICAN WEST 292 (John McLaren, et. al., eds., 1992) (citing speeches from the North Dakota constitutional convention for the point that the drafters rejected the idea of a brief constitution).

59. Amendment to the Egyptian Constitution, AL-JARIDA AL-RASMIYA [Official Gazette] No. 21 Supp. A, 2-6 (May 26, 2005) [hereinafter Text of Amendment].

60. The Nov.-Dec. 2005 PA election results and the current composition of the CA are discussed infra notes 83-85 and accompanying text.

61. Moustafa, Law Versus the State, supra note 27, at 249-250.

62. Text of Amendment, supra note 59, at 4.

63. Id. Thus, nine opposition party candidates were on the ballot along with Mubarak. Lajnat intikhabat al-ri'asa tu'alinu qa'imat man tagaddamu lil-tarshih ghadan [The Presidential Election Committee Will Announce Tomorrow the List of Those Who Applied for Candidacy], Al-AHRAM, Aug. 4, 2005, at 1.

64. Text of the Speech of Mubarak to the Presidents of the PA and CA Regarding the Amendment of Article 76 of the Constitution, supra note 46, at 1. 
The second option in the amendment pertains to independent candidates or candidates whose party does not have the required number of seats in the assemblies. Such candidates must have the support of at least 250 members from the PA, CA, and regional parliaments combined, provided that at least sixty-five signatures are from the PA, at least twenty-five are from the CA, and the candidate has the support of at least ten members from at least fourteen of the twenty-six regional parliaments. Any one member of any of these parliaments may endorse only one candidate. ${ }^{65}$ No independents were able to meet these candidacy requirements in the 2005 presidential elections. ${ }^{66}$ The independent candidates in the PA were not enough, even if they had agreed on one candidate, to provide the minimum number of PA signatures.

According to the amendment, the winner of the presidential election is the candidate who receives votes from an absolute majority of voters. If no one individual receives this number, a run-off election is held seven days later between the two candidates who received the highest vote counts. If a third ties with the second, all three partake in the run-off, and the individual who receives the highest number of votes wins. ${ }^{67}$

\section{Monitoring the Elections}

The monitoring of PA elections has been a significant issue in the past, and the constitution requires under Article 88 that PA voting take place under the supervision of members of a "judicial body." The SCC has ruled on the conformity of monitoring systems with Article 88 and has invalidated an entire PA election, as discussed below. While the constitution did not provide for monitoring of the former presidential referenda, growing popular desire for transparency in legislative elections and in particular demands by judges that they form the monitoring bodies were strong indicators to Mubarak that it would be prudent to include a monitoring system in the constitutional amendment. Thus, he could show that the elections were subject to monitoring but could also, as with the other elements of the new scheme, control the content of the monitoring plan and keep it out of the public and judicial arenas as much as possible.

The constitutional amendment. created the Presidential Election Commission (PEC), which is composed of ten members. The President of the SCC is the President of the PEC, and four more members are also judges: the President of the Appeals Court, the Senior Deputy President of the SCC, the

65. Text of Amendment, supra note 59, at 3. The current status of elections to the regional parliaments is discussed infra notes 87-88 and accompanying text.

66. Nine independents applied for inclusion on the ballot, but none had the requisite signatures and the Presidential Election Commission, see infra notes 68-71 and accompanying text, rejected their applications. Al-lajna istaba' adat 9 talibat li- 'adm istifa'iha al-shurut [The Committee Disqualified Nine Applications Due to Non-fulfillment of the Conditions], ALAHRAM, Aug. 5, 2005, at 1.

67. Text of Amendment, supra note 59, at 5. 
Senior Deputy President of the Court of Cassation, and the Senior Deputy President of the Council of State. ${ }^{68}$ The other five members are individuals without political affiliations and they serve for a term of five years. Three of them are chosen by the PA and two are chosen by the CA. ${ }^{69}$ While these last five members are supposed to be neutral, it is important to remember that since NDP members dominate the PA and CA, their party affiliation likely influences these choices.

The PEC has a broad jurisdiction that includes all matters related to the presidential elections. Furthermore, decisions of the PEC are not subject to appeal. The PEC's areas of competency are:

1. Announcing the opening date in which individuals can seek recognition as a candidate for President, supervising the procedures for this process, and announcing the final list of candidates.

2. General supervision of the procedures of voting and vote counting.

3. Announcing the results of the elections.

4. Deciding all of the complaints, appeals, and all matters related to the PEC's duties, even if it is a dispute over the PEC's own jurisdiction.

5. Drafting procedures for organizing the manner of its work and method of exercising its duties. ${ }^{70}$

The amendment provides that the presidential voting shall take place on a single day and under the general supervision of the PEC. The one-day rule is not a benign practical matter, but it relates to a long history of PA elections in which the SCC required real judicial supervision of each polling station and the regime responded with a proposal to hold elections in phases so that each judicial monitor could conduct monitoring at a different location at each

68. This is the majlis al-dawla (the administrative court). For more information, see $\mathbf{M}$. Rady, Administrative Law, in EGYPT AND ITS LAws 221 (Nathalie Bernard-Maugiron \& Baudouin Dupret, eds., 2002).

69. Text of Amendment, supra note 59, at 4.

70. Id. at 5 . 
phase. $^{71}$ Apparently wanting to avoid this level of judicial scrutiny, Mubarak instead proposed a vertically organized system of monitors. The PEC should establish two types of commissions: general supervisory commissions (GSCs) and technical commissions. The GSCs are composed of members of judicial bodies and they supervise the work of technical commissions, which actually conduct the practical electoral work. The amendment does not seem to guarantee judicial supervision at each polling station since the amendment did not require that technical commissions include members of judicial bodies.

The amendment specifies that after adoption of the constitutional referendum, the President and the PA should prepare implementing legislation, which would then be submitted to the SCC for constitutional review prior to promulgation. The SCC would have fifteen days to review the legislation, evaluate the constitutionality of it, and communicate its results back to the President so that the PA could revise the text accordingly before adopting it. ${ }^{72}$ The troubling issue of pre-promulgation SCC review is discussed in detail in Part IV.C.

\section{The Constitutional Amendment Referendum}

Egyptian constitutional procedure requires that a majority of voters adopt an amendment in a nationwide referendum. ${ }^{73}$ The public announcement of the proposed presidential election amendment and forthcoming referendum was greeted within Egypt and internationally by exuberance, caution, and outright skepticism. Reformist organizations such as human rights NGOs and opposition political parties realized not only the lack of progress but also the significant negative consequences of the amendment and took to the streets in some of the most daring rallies and protests Egypt had ever seen. The three main opposition political parties opposed the amendment. Opposition more generally gathered around the grassroots coalition called Egyptian Movement for Change, which is better known by its slogan "kifaya" (literally, "enough").

The PA submitted the referendum to nationwide vote on May 25, 2005. The referendum was boycotted by the three main opposition parties, the coalition kifaya, and many others on the basis that it did not create genuine presidential elections. ${ }^{74}$ According to the Ministry of Interior, fifty-four percent of the nation's registered voters participated in the referendum, which involved marking either "I agree" or "I do not agree" on the ballot. Official figures reported that eighty-three percent of the voters accepted the amendment. ${ }^{75}$

71. See infra note 124 and accompanying text.

72. Text of Amendment, supra note 59, at 5.

73. Egyptian Constitution, supra note 26, art. 189.

74. The three parties issued a joint statement that the amendment "sanctifies the permanent monopoly of the ruling party over the post of the republic's president." The Race is On, supra note 19.

75. See Approval of the Amendment to the Constitution by a Sweeping Majority, supra note 4 , at 1 . 
However, there have been reports of violent intimidation against opponents of the referendum. ${ }^{76}$

\section{IMPLEMENTING LEGISLATION}

The constitutional amendment specifies that the legislature should draft a law on the organization of the presidential elections. Law 174 on the Presidential Elections was promulgated on July 2, 2005 and expands on the constitutional amendment. ${ }^{77}$ The related laws passed along with Law 174 are: Law 173 on the Exercise of Political Rights; ${ }^{78}$ Law 175 on the PA; ${ }^{79}$ Law 176 on the CA; ${ }^{80}$ and Law 177 on Political Parties. ${ }^{81}$ In conjunction with the amendment and Law 174, these laws create a package of legislation that entrenches the NDP's control over the presidency and the legislature. This part discusses the implementing legislation relevant to the presidential elections, focusing on the process and criteria for becoming a presidential candidate and the monitoring mechanisms for the conduct of presidential elections.

\section{A. Who is on the Presidential Ballot?}

Because the amendment itself was so specific regarding access of candidates to the ballot, Law 174 added little to the qualifications for office, but essentially reiterated the rules established in the amendment for the two kinds of candidates: political party leaders and independents.

PA membership prior to the 2005 presidential elections was discussed above to illustrate the ramifications of the rules for gaining candidacy. ${ }^{82}$ At that time, no party other than the NDP met the five percent rule, and the number of independents was not enough to nominate a candidate. Hence, the lifting of the five percent rule for the first presidential elections under the new system was necessary in order to have the promised multi-candidate elections. Further examination of these candidacy rules shows the challenges non-NDP candidates will face in future presidential elections.

A political party needs to hold five percent of the seats in both the PA and

76. Hassan M. Fattah, World Briefing Middle East: Egypt: Multicandidate Vote Approved, N.Y. TIMES, May 27, 2005, at A1.

77. Law 174 (2005), AL-JARIDA AL-RASMIYA [Official Gazette] No. 26 Supp., 11-24 (July 2,2005 ). The SCC's review of a draft of this law is discussed infra note 157 and accompanying text.

78. Law 173 (2005), AL-JARIDA AL-RASMIYA [Official Gazette] No. 26 Supp., 3-10 (July 2, 2005) (amending Law 73 (1956)).

79. Law 175 (2005), AL-JARIDA AL-RASMIYA [Official Gazette] No. 26 Supp., 25-27 (July 2, 2005) (amending Law 38 (1972)).

80. Law 176 (2005), AL-JARIDA AL-RASMIYA [Official Gazette] No. 26 Supp., 28 (July 2, 2005) (amending Law 120 (1980)).

81. Law 177 (2005), AL-JARIDA AL-RASMIYa [Official Gazette] No. 26 Supp., 3-10 (July 7,2005 ) (amending Law 40 (1977)).

82. See supra notes $60-61$ and accompanying text. 
CA to nominate a presidential candidate. There are 264 seats in the CA, and two-thirds (176) of them are elected and one-third (88) are appointed by the President. Members serve six-year terms, and half of the members are replaced every three years. The composition of the CA is nearly exclusively NDP members. $^{83}$

The 2005 PA elections, held in three phases on November 7 and 10 and December 1, 2005, did result in substantial losses for the NDP and equivalent gains for independent candidates. The changes, however, still offer non-NDP members little hope of becoming presidential candidates in the 2011 elections. In the 2005 PA elections, the NDP won 311 seats; al-Ghad won one; Tajammu won two; the New Wafd Party won six; and 112 independent candidates won seats. ${ }^{84}$ Of the winning independents, it is estimated that 88 of the candidates are affiliated with the Muslim Brotherhood. Since the Egyptian government has deemed the Muslim Brotherhood an illegal organization, Muslim Brotherhood members must run as independents. However, it is generally known which candidates are Muslim Brotherhood members and the government has generally tolerated this constructed independent status. ${ }^{85}$ Thus, it is still the case that no party other than the NDP meets the threshold of holding five percent of the seats in the PA.

The hope for non-NDP candidates seems to be with the independent nominee option. Law 174 reiterates the rules for independent candidates accessing the ballot: they must have the support of at least 250 members from the PA, CA, and regional parliaments combined, provided that at least sixtyfive signatures are from the PA, at least twenty-five are from the CA, and they also must have the support of at least ten members from at least fourteen of the

83. Gamal Essam El-Din, NDP versus NDP - Yet Again, AL-AHRAM WEEKLY, May 6-12, 2004, available at http://weekly.ahram.org.eg/print/2004/689/eg6.htm. CA elections are considered by the opposition to be a "no-contest battle." Id. Since the CA is only a consultative body, opposition groups prefer to put their energy and money into contesting the more significant PA elections. Id. Al-Ahram Weekly is an English-language weekly newspaper published in Cairo. While is it related to the daily official Arabic-language newspaper $\mathrm{Al}$ Ahram, the journalists for Al-Ahram Weekly are generally more willing to write articles that criticize aspects the state, and the state allows them to since the majority of Egyptians are not able to read the English-language paper and thus are not exposed to these views. The Englishlanguage Al-Ahram Weekly and its French counterpart are mainly for the consumption of foreigners in Egypt.

84. Mohamed Sid-Ahmed, After the Elections, Al-Ahram WeEKLY, Dec. 15-21, 2005, available at http://weekly.ahram.org.eg/print/2005/773/op3.htm.

85. Id. One interpretation of the gains made in the 2005 People's Assembly elections by candidates known to have affiliations with the Muslim Brotherhood, for example, is that the NDP allowed these candidates to increase their seats in the People's Assembly-although not enough to challenge the NDP's control-to show Egypt and the rest of the world on a small scale what might result in completely free elections. Neil MacFarquhar, Stirrings in the Desert, N.Y. TimeS, Dec. 8, 2005, at A18. "Some analysts argue that the [Egyptian] government's strategy was to let the Brotherhood win just enough seats to force critics both here and in Washington to confront the fact that the choice comes down to the governing party or the abyss." Id. 
twenty-six regional parliaments. Any one member of any of these parliaments may endorse only one candidate. ${ }^{86}$

Regional elections were scheduled for April 2006, but on February 12, 2006 the CA approved the postponement of these elections until April 2008. ${ }^{87}$ The President of the CA stated that the purpose was to allow time for the drafting of a new local administration law. Commentators persuasively speculated that the postponement was due to the success of the independent candidates in the PA elections in December 2005 and the regime's fear that if they did as well at the regional level, an independent presidential candidate in 2011 might become a possibility. The Muslim Brotherhood opposed the postponement, and they were the ones who would presumably have done well in the regional elections given their success in the PA elections. ${ }^{88}$

Since the number of supporters needed by independent candidates to gain candidacy far exceeds the number of seats a political party must hold in order to nominate a candidate, it would seem logical for groups of the independent members of the PA and CA to form a party in order to gain more nominating power. However, party registration and the requisite maintenance of registration status is burdensome. The registration and activities of political parties are regulated by the Law on Political Parties, which was amended by Law 177 of $2005 .^{89}$ The Political Parties Committee (PPC) is responsible for implementing the legislation. The PPC is composed of nine members: the President of the CA, Minister of Interior, Minister of PA Affairs, three former members of judicial bodies who are not affiliated with a political party, and three individuals also unaffiliated to a political party. These last six individuals are appointed by the President for renewable terms of three years. ${ }^{90}$ Since the President also appoints Ministers, and the President of the CA is a member of the NDP, the executive essentially controls the PPC.

The regulations for forming a political party are strict and include, for example, the requirement that the program of the party must represent an addition to the political life of the country according to the party's specified goals and methods. ${ }^{91}$ Of the twelve political parties formed since the 1970 s, the PPC initially denied registration to eleven of them. The leaders of the proposed parties each filed a complaint in the courts, which uniformly overturned the PPC's decision. ${ }^{92}$ There are clear parameters in the law for the perspectives that a party might represent. A party may not be formed on the basis of

86. Text of Amendment, supra note 59, at 3.

87. United Nations Development Programme, Programme on Governance in the Arab Region (POGAR), Elections: Egypt, available at http://www.pogar.org/countries/elections.asp?cid=5 (last visited April 26, 2006).

88. AP, World Briefing Middle East: Egypt: Parliament Postpones Elections, N.Y.T., Feb. 15, 2006, Section A.

89. Law 177, supra note 81 .

90. Id. at art. 8.

91. Id. at art. $4(3)$.

92. United Nations Development Programme, supra note 87. 
religion, whether in its fundamental principles, program, activities, or choice of leaders or members. ${ }^{93}$ The Muslim Brotherhood, for example, would not be permitted to register as a political party under these rules, even if it were not otherwise considered an illegal organization by the administration. ${ }^{94}$

In order to apply for party registration, the group must have at least 1,000 signatures from its founding members, and of these, there must be at least fifty signatures from individuals residing in at least ten provinces. ${ }^{95}$ The PPC has ninety days to issue its decision, and if it denies party registration it must give its reasons for the rejection. ${ }^{96}$ A rejected party may appeal within thirty days to the first level of the Council of State, which is the administrative court. ${ }^{97}$

Once a party is registered, it must abide by the rules established by the PPC, and its registration may be dissolved or suspended for infractions. The President of the PPC, with the approval of PPC members, may request the Council of State to issue a judgment dissolving a party for violating any of the registration criteria, and the Council of State will hold a session to consider the request for dissolution. ${ }^{98}$ If required by the exigencies of the national interest and in a situation of need for expedited action, the PPC may itself temporarily suspend a party's activities, one of its leaders, or any decision or action taken by the party instead of requesting that the Council of State take the steps to dissolve the party. The suspended party may appeal the suspension within seven days to the Council of State. If the suspension is not overturned, the party may petition the Council of State to lift the suspension after three months. If the Council of State refuses, the party may attempt again after three months. 99 This suspension option seems to have no time limit. For example, the Labor Party lost recognition in 2000 and has not yet regained it. ${ }^{100}$

As this discussion has shown, the ability for a political party to nominate a presidential candidate, or for an independent to succeed in becoming a candidate, is closely tied to the composition of the PA, CA, regional parliaments, and to the authority of the executive. The representative nature of these bodies, and the possibility for candidates other than from the NDP to be elected to them, is in turn dependent on the fairness of the elections to these bodies. As will be discussed in the following section, election supervision is crucial for fair presidential elections, but non-NDP candidates will not even be able to run for president if the PA, CA, and regional parliaments remain NDP-

93. Law 177, supra note 81 , at art. 4(4).

94. See Egypt Country Reports, supra note 49.

95. Law 177 , supra note 81 , at art. 7.

96. Id. at art. 8 .

97. Id.

98. Id.

99. Id.

100. The PPC suspended the Labor Party and its affiliated newspaper, $a l-S h a ' b$, after the Labor Party led a campaign against the Minister of Culture for publishing a novel that the Islamist-oriented Labor Party claimed insulted Islam. Khaled Dawoud, Party in Distress, ALAHRAM WEEKLY, July 19-25, 2001, available at http://weekly.ahram.org.eg/2001/543/eg5.htm. 
dominated. Thus, the fairness of the PA, CA, and regional parliament elections is essential.

Below, I first provide an overview of the election supervision scenario in Egypt for purposes of background. Next I will address the definition of "free and fair" elections. Then I will outline the new presidential election supervision system. Finally, I will conclude with the new general (i.e., other than presidential) election supervision system, promulgated as Law 173 on the Exercise of Political Rights on the same day as Law 174 on the Presidential Elections. While Law 173 deals with all elections other than the presidential elections, the tight relationship between the composition of the PA, CA, and regional parliaments and the presidential election process explains why the government considered these laws interrelated and necessary to promulgate as one legal package.

\section{B. Who Monitors the Elections?}

\section{The Troubled History of Egyptian Elections}

While both the PA and part of the CA are elected, the PA elections are more significant because the body has legislative power. PA elections are held every five years and fairness in these elections had been a serious issue for several decades. Only in recent years have opposition parties and human rights groups been able to bring this issue to public light and seek recourse through public pressure and the courts for fraudulent behavior in elections. The 1990 elections were highly problematic, and a significant court case resulted, which is discussed below. However, the opposition community was not sufficiently organized at that time to mobilize and document the widespread abuses. ${ }^{101}$

In the months prior to the 1995 PA elections, opposition parties sought to prevent a repetition of past election irregularities by calling upon the administration to allow international observers access to polling stations. The regime refused. In response, the opposition parties, human rights organizations, and professional syndicates joined forces to conduct their own monitoring, and they formed the Egyptian National Commission to Monitor the 1995 Legislative Elections (the "1995 Commission"). 102 .

In the days before the 1995 election, the 1995 Commission received over 1,000 complaints from candidates about harassment from government officials

101. For a discussion of the 1990 elections, see EBERHARD KIENLE, A GRAND Delusion: DEMOCRACY AND ECONOMIC REFORM IN EGYPT 59-88 (2000).

102. The history of the formation of the 1995 Commission and their detailed findings are documented in IBN KHALDUN CENTER ET AL., SHAHADAT LIL-TARIKH: TAQRIR AL-LAJNA ALWATANIYA AL-MISRIYA LI-MUTABI'A AL-INTIKHABAT AL-BARLAMANIYA 1995 [WITNESS TO HISTORY: REPORT OF THE EGYPTIAN NATIONAL COMMISSION TO MONITOR THE 1995 LEGISLATIVE ELECTIONS] (1995) [hereinafter WITNESS TO HISTORY]. Dr. Sa'd El-Din Ibrahim of the Ibn Khaldun Center was the Secretary General of the 1995 Commission. 
and irregularities in the voter registration lists. In investigating these reports, the 1995 Commission found that sixty-nine percent of the confirmed complaints dealt with voting lists in which an individual was listed more than once. ${ }^{103}$ For one polling station in Helwan, on the outskirts of Cairo, the Commission received a complaint that at least 750 voters were listed more than once, for a total of more than 2,000 duplicate names out of a voting list of $14,000{ }^{104}$

The 1995 Commission also documented the Mubarak regime's crackdown on opposition candidates in the months prior to the elections. Between November 15 and December 12, 1995, 1,392 Islamists and opposition party members were detained. Most of the detentions occurred just days before the first round of elections to hamper the ability of opposition candidates to send their supporters to the polling stations to watch for government orchestrated election fraud. ${ }^{105}$

The 1995 Commission recorded a substantial amount of irregularities in the voting process itself. Over 1,000 complaints were filed from candidates and voters on the first day of the election, most coming from the Islamist-oriented Labor Party. ${ }^{106}$ One hundred forty-nine complaints alleged that the managers of the polling stations refused to open ballot boxes to confirm that the boxes were empty before voting began. ${ }^{107}$ As a result of the 1995 parliamentary elections, the NDP further strengthened its dominance in the PA, controlling ninety-four percent of the seats. ${ }^{108}$ Four opposition parties combined won a total of only thirteen seats. ${ }^{109}$

The 1995 elections were considered the most corrupt and violent up to that time, resulting in sixty deaths and over 800 injuries. ${ }^{110}$ Following these elections, opposition parties searched for a forum to present their complaints, and turned to the SCC to challenge the constitutionality of then-existing election procedure. ${ }^{11}$ Specifically, they focused on Article 88 of the Constitution. ${ }^{112}$ Article 88 provides that for PA elections and referenda, voting must take place under the supervision of members of a "judicial body."113 Opposition activists challenged the 1995 elections on the grounds that members

103. Id. at 35 .

104. Id. at $40-41$.

105. Moustafa, Law Versus the State, supra note 27, at 190 (citing Egyptian Organization for Human Rights, DEMOCRACY JeOPARDIZED: NOBODY PASSED THE EleCTIONS (1996)).

106. WITNESS TO HISTORY, supra note 102 , at 35 .

107. Id. at 35 .

108. Moustafa, Law Versus the State, supra note 27, at 193.

109. Id.

110. Id.

111. Id. at 195 .

112. Id.

113. Egyptian Constitution, supra note 26, art. 88. The article states: "The qualifications for membership in the People's Assembly will be established by a law that will also explain the rules for selection [of the members] and for referenda, provided that the voting process is conducted under the supervision of members of a judicial body." Id. 
of judicial bodies did not supervise every polling station in the country, which includes main stations and branch stations. State employees were permitted to, and in fact in large numbers did, supervise branch polling stations, where the majority of electoral forgery allegedly occurred. ${ }^{114}$ Because a constitutional issue was implicated in these claims, the constitutional matter was transferred to the SCC. A similar claim had been filed by defeated opposition candidate Kamal Khalid from the 1990 elections, and by 1995 this claim was making its way through the court system but had not yet been decided by the SCC. ${ }^{115}$

Leading up to the 2000 elections, the interests of opposition leaders, NGOs, and judicial personnel converged. ${ }^{116}$ Opposition party leaders in the PA submitted legislation to amend Law 73 on the Exercise of Political Rights to provide election supervision and administration by a supreme election commission composed of nine high-ranking judges from the Court of Cassation and Court of Appeals, rather than allowing the elections to be operated as usual by the Ministry of Interior. The legislation also called for an updating of existing voter lists, full judicial supervision of all polling stations, and general safeguards to reduce the possibility of fraud in the voting process. ${ }^{117}$ Egyptian judges and NGOs announced their support for the amendment. However, since the opposition in the PA proposed this amendment and it did not serve the interests of the NDP members of the PA, it had no chance of adoption.

This combined pressure from judges, NGOs, and opposition parties, however, did cause the Egyptian administration to initiate its own amendment in hopes of quieting the opposition without fully giving in to their demands. ${ }^{118}$ The administration claimed that with only 5,661 judges available to monitor elections, these judges simply could not supervise the nation's total of 42,000 polling stations. ${ }^{119}$ In response, the PA adopted an amendment to the Law on the Exercise of Political Rights to assign one judge six to eight polling stations to supervise. ${ }^{120}$ This was a largely meaningless amendment because one judge could not adequately supervise multiple polling stations on the same election day.

Judges were particularly concerned about this new scheme. By playing a more extensive, yet still inadequate, monitoring role, they feared that they would be used to legitimize an election that they expected to be rife with electoral fraud. The Judges' Club subsequently announced that judges would either be continuously present at all polling stations or they would abstain

114. Moustafa, Law Versus the State, supra note 27, at 196.

115. See discussion infra notes $122-123$ and accompanying text.

116. Moustafa, Law Versus the State, supra note 27, at 234-35.

117. Id. at 235 .

118. Id. at 236.

119. Id.

120. Law 13 (2000), AL-JARIDA AL-RASMIYA [Official Gazette] No. 15 Supp., 5-7 (April 15, 2000) (amending Law 73 (1956)). 
completely from monitoring the elections. The administration refused to accept this demand. ${ }^{121}$

The dispute over judicial supervision of the voting process was unexpectedly settled by a significant ruling from the SCC on July 8,2000 , just a few months after the PA's amendment to the Law on the Exercise of Political Rights. ${ }^{122}$ As mentioned above, defeated opposition candidate Kamal Khalid filed a constitutional claim in 1990 alleging fraud in the electoral process. The SCC held that the 1990 PA elections violated Article 88 because each polling station was not supervised by a member of a judicial body. The SCC stated that Article 88's requirement of judicial supervision means that the supervision must be actual, not superficial or nominal. ${ }^{123}$ This decision clearly affected the ongoing debate over monitoring of the upcoming 2000 PA elections. Opposition parties and NGOs saw a victory in the SCC's ruling.

In response to the SCC's ruling, Mubarak issued a presidential decree ordering that the 2000 PA elections take place in three phases, and in each phase elections would be held in about one-third of the nation's governorates. Some branch voting stations were consolidated to reduce the number of voting stations nationwide. ${ }^{124}$ Thus, each voting station on its particular election day could be supervised by a member of a judicial body.

The Judges' Club was concerned that their monitoring involvement was limited to a narrow window of supervisory activity on election day. They also objected to continuing executive involvement in the electoral process; since ultimate oversight of the elections remained with the Ministries of Interior and Justice, both Presidential appointees. ${ }^{125}$ Some judges began to focus on another issue, which would figure more prominently in subsequent elections: the meaning of the phrase "judicial body" in Article 88. The phrase is not defined in the Constitution itself but is used in the 1972 Law 46 on Judicial Authority. ${ }^{126}$ Based on its use in Law 46, the meaning is very broad and includes not only judges but also lawyers for the state, including public prosecutors and state defense lawyers. ${ }^{127}$ Some judges opposed accepting them

121. Moustafa, Law Versus the State, supra note 27, at 237. The Judges' Club was initially a mainly social club, but throughout the 1990s it began to take positions on matters of judicial politics and it remains very active in judicial and electoral affairs. The leadership of the Judges' Club is elected from among the membership. The official supervisory body of the judiciary is the Supreme Judicial Council, composed of appointees of the executive and headed by the Minister of Justice.

122. Supreme Constitutional Court of Egypt, Case No. 11, Judicial Year 13 (July 8, 2000), AL-JARIDA AL-RASMIYA [Official Gazette] No. 29 Supp., 47-59 (July 22, 2000).

123. Id. at 55 .

124. Presidential Decree 372 (2000), AL-JARIDA AL-RASMIYA [Official Gazette], No. 37 Supp., 2-3, (September 17, 2000).

125. Moustafa, Law Versus the State, supra note 27, at 241-42.

126. Law 46 (1972), AL-JARIDA AL-RASMIYA [Official Gazette], No. 40, 586-609 (Oct. 5, 1972) (most recently amended by Law 159 (2003), AL-JARIDA AL-RASMIYA [Official Gazette] No. 38 Supp., 2-3 (Sept. 25, 2003)).

127. See id. 
as judicial monitors on the grounds that they owe their loyalty to the state and its ruling party.

Following the three-stage 2000 PA elections, Egyptian NGOs concluded that the election was cleaner inside the polling stations, but they complained that coercion occurred outside the stations in the days and weeks prior to the elections. ${ }^{128}$ None of these contentious issues were resolved in the aftermath of the 2000 PA elections. Since members of "judicial bodies" oversaw the balloting in the polling stations, the administration was technically in compliance with the SCC decision of July 8, 2000 .

\section{A Standard for Free and Fair Elections?}

While reports of Egypt's legislative elections clearly indicate severe voting irregularities, a standard is necessary to determine what level of irregularities will make an election unacceptable. Egyptian human rights organizations and opposition parties have documented cases of what appears to be outright fraud, as well as more subtle vote tampering, and these may be the best definitions to work with for the Egyptian context. ${ }^{129}$ Nevertheless, before turning to the 2005 Egyptian presidential elections, it is important to assess the standard the international community uses to determine free and fair elections.

International election monitoring organizations have recognized that no country has pristine election practices; rather, the question is whether the election is good enough ${ }^{130}$ This section briefly reviews current standards used by international monitoring organizations in order to provide some measure with which to evaluate the Egyptian election system. International election observers generally consider as fundamental "independent electoral authorities, separate from the government or political parties, to oversee election administration and the interpretation and implementation of applicable election laws." 31 According to former U.S. President Jimmy Carter, "[t]he consolidation of democracy requires that the institutions that manage the electoral process be independent, competent, and perceived as completely fair by all the candidates participating in the process." 132

128. Moustafa, Law Versus the State, supra note 27, at 244.

129. See WITNESS TO HISTORY, supra note 102 , at 41 .

130. Jimmy Carter stated that "[i]f we were invited to go into a foreign country to monitor the election and they had similar election standards and procedures [as did Florida], we would refuse to participate at all." Interview by Bob Edwards with former U.S. President Jimmy Carter, Morning Edition (National Public Radio broadcast, Jan. 9, 2001).

131. ERIC C. BJornLund, BEYOND FreE AND FaIR: Monitoring EleCtions AND BUILDING DEMOCRACY 4 (2004).

132. Carter Center's Council of Freely Elected Heads of Government and National Democratic Institute for International Affairs (NDI), quoted in 1990 ELECTIONS IN THE DOMINICAN REPUBLIC: REPORT OF AN OBSER VER DELEGATION 20 (Washington, D.C.: Council of Freely Elected Heads of Government and NDI, 1990). In the United States, state and local elections are run by local political officials. BJORNLUND, supra note 131, at 4 . 
Independent electoral monitors are only effective in identifying irregularities and fraud to the extent that they employ a methodology that allows them to witness and document electoral problems. Domestic and international observers typically use different approaches and, as a result, can achieve different goals. While domestic observers are far more familiar with the local terrain, international observers are better funded and attract high-profile news coverage. Yet, by not having a long term attachment to the site of the elections and lengthy experience with the region, international monitors have been criticized for "plac[ing] too much emphasis on election mechanics and election day itself," with the result that the observation can be superficial. ${ }^{133}$ In the face of international scrutiny, authoritarian governments will often hold "Potemkin village" elections in an attempt to control the substance while still putting up a front of a true election to please the international community, especially donor nations. ${ }^{134}$ In any case, international observers require the permission of the host government to monitor elections, and the Egyptian administration has consistently refused to allow any outside monitoring. ${ }^{135}$

International monitoring organizations recognize the potential power of domestic election monitoring and often the two types of groups cooperate in the monitoring process. Non-partisan domestic election-monitoring organizations emerged in the late 1980s and early 1990s in virtually every region of the world and contributed greatly to a global movement for democracy. ${ }^{136}$ This is the main avenue of development for Egypt. NGOs played an active role in the 1995 legislative elections, a lesser role in the 2000 elections, and were able to shadow the 2005 presidential elections.

133. BJORNLUND, supra note 131 , at 13 .

134. Id. at 14.

135. See United Nations Development Programme, supra note 87 (stating that only after an Administrative Court ruling did the government allow a small number of representatives of Egyptian NGOs to observe the presidential elections).

136. BJORNLUND, supra note 131 , at 38-39. Bjornlund provides the important history of domestic election monitoring:

[It] began in the Philippines in the mid-1980s with the pioneering experience of the National Citizens' Movement for Free Elections (NAMFREL), which has inspired many similar efforts around the world. Since then, in more than sixty countries and in every region of the world, nonpartisan domestic electionmonitoring organizations (EMOs) have provided momentum to the struggle for democracy by working to ensure that elections are competitive and meaningful. . .. Domestic coalitions of NGOs, human rights groups, professional associations, social service organizations, university students, and others have worked effectively together to monitor important transitional or otherwise controversial elections in places as diverse as Bangladesh, Kenya, Mexico, Ukraine, and Yemen. EMOs have contributed to more genuine election processes by encouraging fairer campaign practices and a more informed electorate, as well as by reducing the possibility of fraud and irregularities on election day. 


\section{Presidential Election Monitoring}

The history of election fraud in Egypt demonstrates why monitoring the presidential elections in Egypt is an important piece in the larger picture of allowing Egyptians to freely and fairly choose their leaders. Even if the issues regarding criteria for candidacy are resolved to make multi-candidate elections possible on a continuing basis, the presidential elections will remain susceptible to electoral fraud and abuse until adequate monitoring mechanisms are put into place.

The requirement of supervision of presidential elections has an unclear legal status. Article 88 regarding supervision by members of a "judicial body" is in the section of the Constitution on PA elections, and the Constitution did not provide for supervision of presidential referenda under former Article 76. The Judges' Club met on May 13, 2005 and adopted the position that it would refuse to participate in monitoring the presidential elections unless the government gave the judges full independence in their monitoring efforts. The impact of this threat was unclear because there seemed to be no constitutional requirement to have judges of any kind monitor presidential elections. In practice, however, the threat was viable to the extent that the Egyptian administration needed judges' participation and endorsement to show that the elections were free and fair. ${ }^{137}$

President Mubarak clearly wanted to address the issue of monitoring presidential elections through constitutional means rather than provide for it later in implementing legislation. As discussed above, legislation is subject to SCC review and possible invalidation on grounds of unconstitutionality, and since the SCC had intervened to rule on the constitutionality of PA elections, the regime did not want to provide an opportunity for scrutiny of the presidential election process. Law 174 gave some role to judges, although not the complete horizontal and vertical supervision the Judges' Club had wanted. Law 174 reiterates the statement from the constitutional amendment, discussed

137. The Race is On, supra note 19, at 161. Related to the demand for full independence in monitoring the elections, the Judges' Club also has demanded a new law regulating the judiciary in order to reduce the executive's control over the judiciary through the Supreme Judicial Council. Mona Nahhas, Judicial Stand Off, AL-AHRAM WEEKLY, Feb. 23-March 1, 2006, available at http://weekly.ahram.org.eg/print/2006/783/eg8.htm. This issue continued to develop after the 2005 presidential and legislative elections. The Supreme Judicial Council remove the immunity of four senior judges who had been advocating judicial independence from the executive. Id. The Minister of Justice referred two of these four judges-who were also leading critics of fraud in the last presidential and legislative elections-to a judicial disciplinary court, sparking demonstrations in front of the Judges' Club by pro-reform judges and activists. Mona Nahhas, Judges Refuse to Budge, AL-AHRAM WEEKLY, May 4-10, 2006, available at http://weekly.ahram.org.eg/print/2006/793/eg6.htm. The government sent thousands of anti-riot police to quell the growing demonstrations, and recently the police detained about fifty demonstrators under the emergency law, the continual renewal of which is another complaint of pro-reform activists. Michael Slackman \& Mona El-Naggar, Egyptian Forces Beat Back Demonstration for Judges, N.Y.TIMES, May 11, 2006, at 11. 
above, that the PEC should establish two types of commissions: general supervisory commissions (GSCs) and technical commissions. The GSCs are composed of members of judicial bodies and they supervise the work of technical commissions. The technical commissions conduct the practical electoral work, and there is no requirement that they contain members of judicial bodies. ${ }^{138}$

The jurisdiction of the GSCs extends to "all matters connected to the electoral procedure, and determining the correctness or invalidity of providing any voter with a ballot." 139 After the voting ends and the technical commissions have completed their work, the president of the corresponding GSC gathers the ballots from all of the voting stations and confirms in writing what each candidate received in each polling station, signs off on this document, and sends the report to the PEC. ${ }^{140}$ This statement suggests that the GSCs are not required to be present at the voting stations during the voting process but only count the ballots afterwards. Within three days of receiving the reports from the GSCs, the PEC announces the general results. ${ }^{141}$

While Law 174 provides for a new monitoring body, the PEC, the details of the monitoring itself leave room for concern that the monitors best positioned to catch election irregularities, the members of the technical commissions, are not independent, neutral observers. The PEC's authority is not subject to appeal, and half of its members are chosen by the NDP-dominated legislature.

\section{Legislative Election Monitoring}

Law 173 of 2005 on the Exercise of Political Rights went into effect on the same day as Law 174. ${ }^{142}$ Law 173 applies to all elections other than the presidential elections and primarily provides for a monitoring mechanism. Law 173, like the constitutional amendment and Law 174, reflects the administration's desire to show attempts at democratic developments while actually continuing tight control of the electoral process. ${ }^{143}$ The PA elections, regional parliaments, and CA elections for the elected seats are important events in terms of the ability of those bodies to nominate presidential candidates. Thus, the rules established by Law 173 are closely tied to the presidential election system.

Law 173 creates the Supreme Elections Commission (SEC), composed of eleven members. The SEC's jurisdiction is broad and includes the following:

1. Drafting rules for the preparation of voter lists, their contents, and the method of verifying, sorting, and updating it.

138. See Law 174, supra note 77, at art. 34 .

139. Id. at art. 36 .

140. Id. at art. 38.

141. Id. at art. 39.

142. Law 173 , supra note 78.

143. See id. at art. 2(bis). 
2. Making suggestions for rules for defining the electoral departments.

3. Drafting rules for ordering the use of campaign materials.

4. Participating in efforts of education, creating awareness related to the elections, and drafting instructive rules to operate the electoral process.

5. Ensuring compliance with agreements of supervision related to the elections.

6. Announcing the overall result of an election or referendum.

7. Issuing an opinion regarding plans for specific election laws. ${ }^{144}$

The Minister of Justice serves as President of the commission. Three members are current judges at either the level of Vice President of the Court of Cassation or of the same rank. Six members are individuals not affiliated with a political party, and they serve a term of six years. Four of these six are chosen by the PA, and at least two of them must be retired members of a judicial body. The other two are chosen by the CA, and at least one must be a retired member of a judicial body. The eleventh member is a representative of the Ministry of Interior. ${ }^{145}$ As a result, the members of the SEC are even more aligned with the administration and the NDP than are the members of the PEC.

As discussed above, international election observers generally agree that independent electoral authorities should oversee the election process and that they should be separate from the government or political parties. While the SCC decision of July 8, 2000 requires each polling station for PA elections to be supervised by a member of a judicial body, some judges believe that the broad definition of judicial body compromises the integrity of judicial supervision. Further, the ultimate authority for all elections other than the presidential election is the SEC. The membership of the SEC creates substantial doubt that Egypt is meeting these standards.

144. Id. at art. 3(c).

145. Id. at art. 2 (bis). 


\section{CONSTITUTIONAL AUTHORITY AND SUBVERSION}

The previous sections of this Article analyze the content of the constitutional amendment and the package of implementing legislation, placing the provisions in their historical and political context. This section begins with a brief discussion of some exemplary aspects of the tensions between the executive and the SCC. This section then returns to the constitutional amendment itself in order to analyze how the amendment shows that the Egyptian administration has harnessed the authority of the SCC to achieve its own political ends.

This process of authority and subversion manifests itself in two ways. First, the amendment includes a level of detail more conducive to legislation than to the constitution. Second, it required the SCC to conduct a prepromulgation review of the draft law on the presidential elections, and the SCC is not otherwise empowered to conduct pre-promulgation review. These two manifestations reflect the ongoing struggle for power between the executivelegislature and the SCC (and the judiciary more generally), with the Egyptian Constitution as the battleground.

\section{A. Ongoing Executive-SCC Struggle for Constitutional Power}

Mubarak and the SCC have been locked in a cold war, details of which were discussed above in the section on PA election monitoring and the legitimacy of PA election results. Examples of this struggle also include the most recent SCC President appointment and a subsequent request for statutory interpretation.

SCC President Fathi Naguib died suddenly in office in August 2003, and President Mubarak used his power of discretion to appoint the President of the Cairo Court of Appeals, Mamduh Mohieddin Mar'i as the new SCC President. ${ }^{146}$ SCC Presidents were traditionally promoted from within the SCC, although there is no legal requirement to do so. Appointing a new president from outside the SCC was seen as a move by the regime to install a pliant head of court who would serve the regime's interests.

Soon after Mar'i's appointment, the fears that he would be more willing to take a pro-regime position than his predecessors materialized. In March 2004, the SCC had an opportunity to issue a statutory interpretation on an issue related to election monitoring and of great importance to the Mubarak regime: the definition of the cadre of judges who constitute "judicial bodies" for purposes of election monitoring. Since this had been a major issue in the previous legislative elections, the administration wanted to resolve the matter before the 2005 presidential and legislative elections. Following the statutory interpretation procedure, the Prime Minister instructed the Minister of Justice to

146. Changing the Gavel, AL-AHRAM WEEKLY, Aug. 28-Sept. 3, 2003, available at http://weekly.ahram.org.eg/2003/653/egl/htm. 
request an interpretation of the Law on the Exercise of Political Rights and, specifically, the meaning of "judicial body" in that Law. ${ }^{147}$ The SCC took a very broad interpretation, such that any "judicial body" referred to in any legislation counts as a judicial body for purposes of election monitoring. ${ }^{148}$ This interpretation was a loss for the Judges' Club, which has been trying to exclude from election monitoring lawyers from the state who technically carry the appellation of "judge." "149

\section{B. Legislating in the Constitution}

An amendment to Article 76 of the constitution was necessary to change the system from a single-candidate referendum to a multi-candidate election. However, the level of detail in the amendment not only far exceeds the original language of Article 76 but also is highly inconsistent with the terse style of the Egyptian Constitution.

The concept of entrenching in a constitution rules that would otherwise seem more legislative in nature is not an Egyptian innovation. Using the United States as an example, Ruhl has noted that "as modern society has focused debate increasingly on competing visions of social form, advocates have turned increasingly to constitutional amendment proposals as a means of dictating their respective visions." ${ }^{150}$ In addition to the environmental-related amendments that form the basis for his article, Ruhl inventories the following U.S. constitutional amendment proposals: the religious equality amendment, the school prayer amendment, the crime victims' rights amendment, the flag burning amendment, the human life amendment banning abortion, and the equal rights amendment. ${ }^{151}$ He calls these types of efforts "social policy" amendments in contrast to the "operating system" language of the Constitution, and he develops criteria by which to determine whether social policy amendments are conducive to constitutional inclusion. ${ }^{152}$ In general, he argues for limiting constitutional amendments to structural matters and keeping the details of social policy out of the Constitution. ${ }^{153}$

There is a fundamental assumption made in such discussions regarding attempts to amend the U.S. Constitution: entrenchment in the constitution means that a particular policy or agenda is enshrined as the highest form of law,

147. The interpretation procedure is provided for by the Egyptian Constitution, supra note 26, at art. 175 and Law 48 (1979), supra note 29, at art. 33.

148. Supreme Constitutional Court of Egypt, Request No. 2 for Interpretation (March 7, 2004), AL-JARIDA AL-RASmIYA [Official Gazette], No. 10 Supp., 16-24 (March 9, 2004).

149. See supra note 137 and accompanying text.

150. J.B. Ruhl, The Metrics of Constitutional Amendments: And Why Proposed Environmental Quality Amendments Don't Measure Up, 74 NotRE DAME L. REV. 245, 246 (1999).

151. Id. at n.5.

152. Id. at 246.

153. Id. at 270 . 
and the Supreme Court will protect that provision as it would any other constitutional provision. The same assumption should be true in the Egyptian context, in which case it has important implications for the significance of the Egyptian Constitution. The Egyptian regime recognizes that the constitution is a meaningful document and that the SCC has the power to, and indeed will, uphold the constitution. The regime is circumscribed by the constitution, and thus has found a way to harness the constitution and the SCC's strength to its advantage, rather than launch an outright battle. One way to view this amendment is that the Egyptian regime is taking its seriously. ${ }^{154}$

From the perspective of Egyptian constitutionalism, this could be viewed as a positive step. Indeed, the amendment was a tactical move by the administration necessitated by the state of constitutionalism in Egypt today. In the face of a strong and fairly independent SCC, Mubarak had to structure the election reforms carefully to avoid the possibility that the elections would subsequently be challenged on grounds of unconstitutionality, a process that has occurred with a PA election. Mubarak's first line of defense was to carefully include in the constitutional amendment the essential details of the new election system to protect the amendment itself from subsequent SCC review.

The disadvantages or dangers of constitutional entrenchment mirror the advantages. The SCC is now required to uphold the new election system as a constitutional matter, and the system is structured to make it very difficult for non-NDP presidential hopefuls to gain candidacy. The monitoring system seems to leave ample room for abuse. A second amendment revising or rescinding the presidential election scheme would require the same process and is not viable as long as the NDP controls the legislature.

\section{Tampering with Judicial Review}

The amendment included the statement that a draft of the forthcoming

154. Okoth-Ogendo discusses a similar phenomenon in other African constitutions, but without an equivalent of the Egyptian SCC, it is more difficult to claim that the regimes recognized the power of the court and had to take it seriously; rather, they used the court systems because they were a politically expedient way of achieving their agendas. He argues that state elites found that:

the constitutional arena, if properly controlled by [them] offered a more efficient and effective environment for the resolution of political conflicts than even the party and, certainly, the electorate at large. Indeed by translating a political opinion or decision into a constitutional device or norm, state elites gained the added advantage of passing on the problem of enforcement or supervision ultimately to the judicial arm of the government. A run to amend the constitution [to deal with a political crisis] . . . became increasingly attractive as a method of reestablishing equilibrium within the body politic.

Okoth-Ogendo, supra note 12, at 73 (emphasis in the original). He describes a subversion of the constitutional order without the concomitant recognition of constitutional authority because the state's elites are not bound by the constitution rather simply use it to their advantage. Id. 
law on the presidential elections, which was later issued as Law 174 of 2005 on the Presidential Elections and discussed above, must be given to the SCC for pre-promulgation constitutional review. This procedure is not provided for in the constitution or in Law 48, which governs the SCC, and is a highly problematic development for constitutionalism in Egypt.

Specifically, the final clauses of the amendment to Article 76 state:

The President of the Republic of Egypt will present a draft of the Law on the Presidential Elections to the SCC-after the PA adopts it but before the PA promulgates it-for a determination of its compatibility with the constitution. The SCC will issue its decision in this matter within 15 days from the date the draft was presented to it. If the SCC decides that a provision or provisions of the draft law are unconstitutional, the President of Egypt shall return the draft to the PA to revise it according to this decision. In all cases, the decision of the SCC is obligatory for all people and for all authorities of the state. The SCC decision shall be published in the official gazette within three days of its issuance. ${ }^{155}$

Pursuant to this provision, the SCC made five objections to the legislation, which improved the law from the perspective of access of candidates to campaigning, but did not affect the basic structure of the election scheme. $^{156}$ The PA altered the draft of the law to comply with the SCC's comments, promulgated it, and thus Law 174 went into effect on July 2, 2005.

The requirement of pre-promulgation review by the SCC has been a desire of the administration, although as a political matter it has not been able to amend the constitution to provide for this procedure. As early as 1996, Speaker of the PA Fathi Sorour argued that the SCC's interpretation of the constitution was "deviant" and inconsistent with the public good. As a solution, he proposed an amendment to Law 48 to allow the SCC the power of judicial review only of legislation in draft form and only upon the request of the PA. If the SCC reviewed draft legislation and approved it, or required changes and the PA in fact made those changes, then under this proposal the SCC would never again have jurisdiction over the legislation. ${ }^{157}$

Judge Awad el-Morr, President of the SCC at the time of this proposal, fervently rejected the amendment on the grounds that prior review would

155. Text of Amendment, supra note 59, at 5.

156. Supreme Constitutional Court of Egypt, Decision on the Draft of the Presidential Election Law (June 26, 2006), AL-JaRIDA AL-RASmIYA [Official Gazette], No. 25 Supp., 2-9 (June 26, 2005). The SCC objections and comments were minor and included, for example, an objection to the rule that forbade paid campaign advertising on radio or television during the campaign period because it conflicted with the right of the candidate to express his opinion, to spend his campaign funds, and to communicate his campaign platform. Id. at 7 .

157. Moustafa, Law Versus the State, supra note 27, at 209. 
undermine the SCC's integrity and efficacy. ${ }^{158}$ He stated that most courts cannot apprehend the implications of new legislation until it is implemented. ${ }^{159}$ Worse, he claimed, the executive and legislature would use the procedure in a way that would force the SCC to deem legislation constitutional without adequate examination. ${ }^{160}$ At a speech at Cairo University in 2000, he explained how such a system might work:

Do you think that Dr. Fathy Sorour will one day refer to the court a bill and ask it to determine whether it is right or wrong? Do you imagine that the Prime Minister who sends a bill to pass through the People's Assembly will ask for our opinion of it? Do you think we have an opposition [in the PA] with 60 persons who have an interest in asking whether the law is right or wrong? But let us suppose that we had that number in the opposition and they asked us to review a bill. We will even suppose that the Prime Minister has his country's interest at heart and asks us whether the bill is right or wrong. Do you know what the Egyptian Prime Minister would do? He would send you 20 bills on the same day, saying that the cabinet approved these laws, which might be of different years, and ask our opinion in the constitutionality of them all. Every bill would be [] 200 articles long or so, and the Constitutional Court would be required to decide in $\mathbf{3 0}$ days on four, five, or six thousand articles .... They will dump all bills on us to get the seal of approval of the Constitutional Court, and the result would be that the constitutionality of these bills could not be challenged later on .... . If you want to destroy the Constitutional Court, let's shift to prior review. ${ }^{161}$

The Speaker of the PA did not propose such an amendment at that time because the administration was not willing to confront the authority and strength of the SCC.

Still, the administration aimed for a similar result years later by including in the presidential election amendment pre-promulgation review of the subsequent implementing legislation. Speaker of the PA Fathi Sorour commented that when the SCC issued its decision regarding the Law on the Presidential Elections,

158. Awad el-Morr, Lecture, Cairo University (Sept. 25, 2000) (transcribed by Tamir Moustafa) cited in Moustafa, Law Versus the State, supra note 27, at 210-11.

159. Id. at 210.

160. Id.

161. Id. 
[the] PA was correct when it proposed to include in Article 76 the provision of sending the draft law to the SCC before voting on a final version of it, in order that the position of the Presidency is not affected, [since] consequently a decision of the unconstitutionality of the Law will not take place after its promulgation by the PA. ${ }^{162}$

Sorour suggests that his interpretation of the text of the amendment is that any decision of the unconstitutionality of the Law could be made only before its promulgation and not after.

As predicted by former SCC President Awad el-Morr, the SCC was given a short amount of time, just fifteen days, to consider in the abstract the constitutionality of the Law on the Presidential Elections. The Law on the Presidential Elections contains fourteen pages and fifty-eight articles, and the allotted time for review placed a significant strain on the SCC. ${ }^{163}$ The amendment did not state that the Law on the Presidential Elections would be immune from later review by the SCC, but by this pre-promulgation review the administration sought to obtain as much assurance as it could that the new presidential election system is constitutional. ${ }^{164}$

The SCC received the opportunity to address many of these key constitutional questions very soon after the September 2005 Presidential elections. ${ }^{165}$ A complaint submitted to the SCC challenged the constitutionality of the amended Article 76 of the Constitution and challenged certain provisions of Law 174 on the Presidential Elections. In a decision issued on January 15, 2006, the SCC ruled on both of these claims.

With regard to the challenge to the constitutionality of the amended Article 76 of the Constitution, the SCC determined that it did not have jurisdiction over the claim. The Court stated that its jurisdiction as provided for in Article 175 of the Constitution is to conduct "judicial review of the constitutionality of laws and regulations and to undertake the interpretation of legal texts." 166 The SCC cited this provision of jurisdiction and concluded that its mandate does not include the review of the constitutionality of provisions of the constitution, and therefore the claim is outside the Court's jurisdiction. ${ }^{167}$

As for the request to review the constitutionality of Law 174 on the Presidential Elections, the Court made a significant decision that Awad al-Morr

162. Majlis al-sha'b yuwafiqu 'ala ta'dilat al-mahkima al-dusturiya li-qanun intikhabat ra'is al-jumhuriya [The People's Assembly Agrees on the Emendations of the Supreme Constitutional Court for the President Elections Law], AL-AHRAM, June 30, 2005, at 1 (emphasis added).

163. Personal observation by author during this fifteen-day period.

164. Text of Amendment, supra note 59, at 5.

165. Supreme Constitutional Court of Egypt (Jan. 15, 2006), AL-JARIDA AL-RASMIYA [Official Gazette], No. 2 Supp., 9-15 (Jan. 18, 2006).

166. Egyptian Constitution, supra note 26, art. 175.

167. Supreme Constitutional Court of Egypt (Jan. 15, 2006), supra note 165, at 12. 
foreshadowed in his 2000 public speech in which he objected to the idea of imposing prior review on the SCC's jurisdiction. ${ }^{168}$ The SCC stated that Article 76 as amended provided the SCC with the jurisdiction to review the draft law on the presidential elections for its compatibility with the constitution. The SCC then explained that the President gave the SCC the draft as prepared by the PA, the SCC reviewed it, and then issued a decision that stated which provisions were unconstitutional and what those constitutional defects were. The President transmitted this decision to the PA, which revised the draft in accordance with the SCC's comments and promulgated it as Law 174 on the Presidential Elections.

Analyzing the significance of this procedure, the SCC explained that since the PA corrected all of the constitutional ailments that the SCC noted in its June 26, 2005, decision, the SCC has exercised its power of review of the constitutionality of the legislation. The SCC did not address the question of whether it had the power to review the text of Law 174 irrespective of the fact that it reviewed a draft law that was later adopted as Law 174. The SCC avoided this point by simply and formalistically stating that it had already exercised its right of review over this text. ${ }^{169}$

\section{CONCLUSION: COMPARATIVE LAW LESSONS}

This study aimed to demonstrate that there are vast areas of constitutional law that largely have been ignored by U.S. legal scholars, and Egypt's presidential election amendment is one very important example of this neglect. Given its major significance in the power struggles taking place within and among the executive, parliament, and judiciary in Egypt, the lack of attention to the amendment by the U.S. media, policy organizations, and scholars is troubling. The explanation, I believe, is that the amendment and implementing legislation were seen as largely meaningless changes in a legal system that lacks constitutionalism and thus is not worth scholarly energy.

Confining serious scholarly undertakings to legal systems that fit some definition of "mature," "developed," or "functioning" is a regretful yet continuing phenomenon. The comparative law discipline has broadened significantly since the early 1980 s, when the title Law in Radically Different Cultures was used for a West Publishing comparative law textbook that discussed Egyptian law. ${ }^{170}$ For comparative constitutionalism to fully develop, work must be done in new constitutional territory despite, or perhaps because of, the many new challenges it presents. Comparative law scholars need to take lessons from historians, anthropologists, sociologists, political scientists, and linguists in order to make comparative law a truly global enterprise.

168. See supra note 162 and accompanying text.

169. Supreme Constitutional Court of Egypt (Jan. 15, 2006), supra note 165, at 15.

170. JOHN H. BARTON ET. AL., LAW IN RADICALLY DIFFERENT CULTURES (1983). 
In order to approach new constitutional territory, this article suggests that scholars should identify a point of entry into the constitutional framework and structure that will allow an exposition of the most significant tensions and trends. For Egypt, the presidential election constitutional amendment is an ideal opportunity for an analysis of the battle between the SCC and the executive and legislature. Focus on this issue has shown the details of the power and frailty of the SCC and the possible paths that the SCC will take, or be taken, in the future. With this understanding of competing constitutional authority and subversion, scholars and practitioners will be better able to follow constitutional developments in Egypt and appreciate their significance. 
